\title{
Contemporary Art Gallery (Expressionism Architecture)
}

\author{
Fazra Risky Nasution ${ }^{1 *}$, Morida Siagian ${ }^{1}$ \\ ${ }^{I}$ Department of Architecture, Faculty of Engineering, Universitas Sumatera Utara, Medan, Indonesia
}

\begin{abstract}
Some issues prove that the development of art in Medan is relatively slow and does not become a concern of the public because of the availability of minimal and inadequate space, while Medan is a multicultural city in terms of art, many artists in the city of Medan have great potential. The construction of contemporary art gallery aims to meet the needs and facilities of art activities in the city of Medan because Medan does not yet have a decent art gallery for art activities, from exhibitions, artwork making space, to fine arts training venues and also as a center for art development likeness of the City of Medan. This gallery plans to be a productive place or place to introduce and provide attractive insights or knowledge to local people and tourists and to be able to preserve and preserve the fine arts in the city of Medan. The methodology used in this project is by collecting data through from literature review and by doing a site surveys. This building design uses the theme of expressionism architecture, where this building can express the meaning of art that it can be enjoyed visually.
\end{abstract}

Keyword: art gallery, contemporary art

Received 20-06-2020 | Revised 1-07-2020 | Accepted 22-07-2020

\section{Introduction}

Art was basically a process of human beings, which was an experimental form of artists that possessed creativity, emotional, individual, eternal, and universal qualities. By one of the characteristics of art, namely artistic, then craft as a human activity always gives birth to new creations, following the values that develop in society [1].

Painting is an expression of the creator's feelings conveyed to others so that they can feel what the painter feels [2], painting is also a branch of fine art whose expression manifests through two-dimensional works in which elements the main elements in two-dimensional works are lines and colors [3].

*Corresponding author at: Department of Architecture, Faculty of Engineering, University of North Sumatera, Perpustakaan Street, J07 Building, Medan, 20155, Indonesia 
Painting is one of the arts that continues to develop by the times, especially in Medan. The number of senior artists in Medan who produce works that are very extraordinary besides the city of Medan there are also many art galleries. However, the Gallery in Medan still cannot be said to be a place of preservation of Fine Artworks.

Currently, there are several arts organizations in the field of painting in Medan, namely SIMPASSRI, shade umbrella gallery, leachate gallery, TO2 fine art gallery, rows This decision is own to the lack of adequate facilities to

studio, art gallery UNIMED, North Sumatra cultural park, AL gallery. The previous galleries are arguably unfeasible, which only use existing spaces, and do not have the standards of a representative painting gallery. Sometimes the artists do art exhibitions apparently in other places, such as malls and hotels. This decision is own to the lack of adequate facilities to accommodate these art activities.

Several issues originating from the newspaper stated that the city of Medan did not have a decent art gallery, an unattractive place that made art galleries reluctant to visit, nor did it have the standards of an art gallery. Therefore we need a space in the form of an Art Gallery in Medan that can accommodate all activities related to the work of art in Medan.

\section{Literature Review}

Contemporary Art Gallery is a space that can facilitate all contemporary art activities that are made more directed towards the present. Starting from exhibition activities, discussions of field artists, painting training to the public [4]. The art gallery projects to have flexibility in space, great circulation of visitors and goods, and the arrangement of alluring items. Gallery facilities, which are generally available in galleries, include showrooms, storage rooms, workshop rooms, office space, art shops, and supporting facilities such as lobbies, cafeterias, toilets, parking lots. Architecture Expressionism emphasizes the spiritual and emotional side of the functional aspects of the building. The building regards as a place of expression of the architect's mind [5].

\section{Methodology}

Stages of design by studying the understanding and elemental things about the Gallery, the comprehension of contemporary art, standards regarding the spatial in the Gallery, comparative studies of several Fine Art Galleries. There was also a review of the location of the Gallery and a discussion of design concepts with an emphasis on architectural expressionism. The site used is the site in Medan that is suitable for the place for the Art Gallery. It also discussed the mass layout and space of the building, the appearance of the building, the structure, and the utility used in the design of the contemporary art gallery. 


\section{Result and Discussion}

Contemporary Art Gallery so that art can continue to develop and have a space that can facilitate all art activities and the contemporary gallery is a space to exhibit the results of 2dimensional and 3-dimensional artworks that are advancing at present. The design location is on Cik Ditiro street -in Madras Hulu Village, Medan Polonia District. This area is in the commercial zone (k-1), which is suitable for commercial gallery functions (Figure 1).

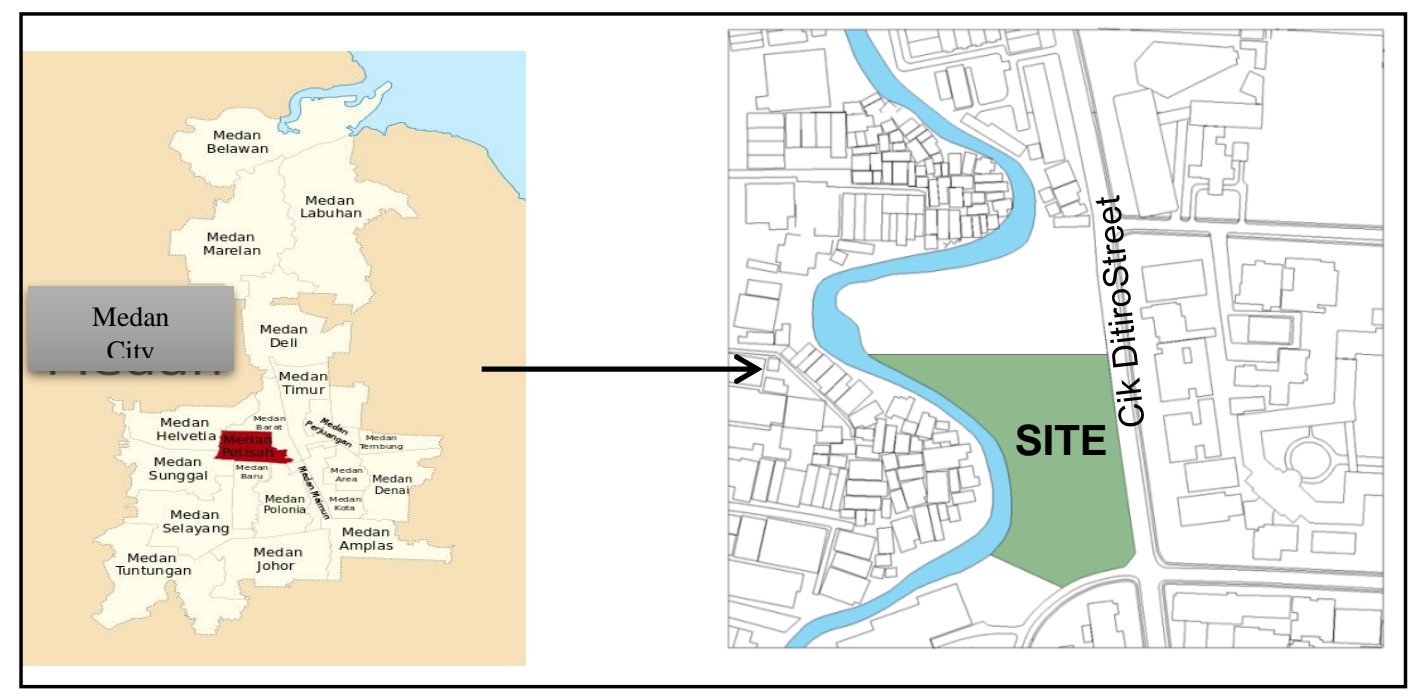

Figure 1 Project Location

Seeing and enjoying paintings is an expression of visitors who will form in the gallery, the interpretation that forms the basis of the basic concept is the use of "sky cross" in buildings where visitors must surround all gallery spaces by enjoying paintings and rivers. The site plan concept in the gallery is an outdoor space concept that makes the river as part of the gallery's outdoor space that supposed to be enjoyed where public activities are on the river's edge, such as an open exhibition area, coffee shop area, and amphitheater (Figure 2-3).

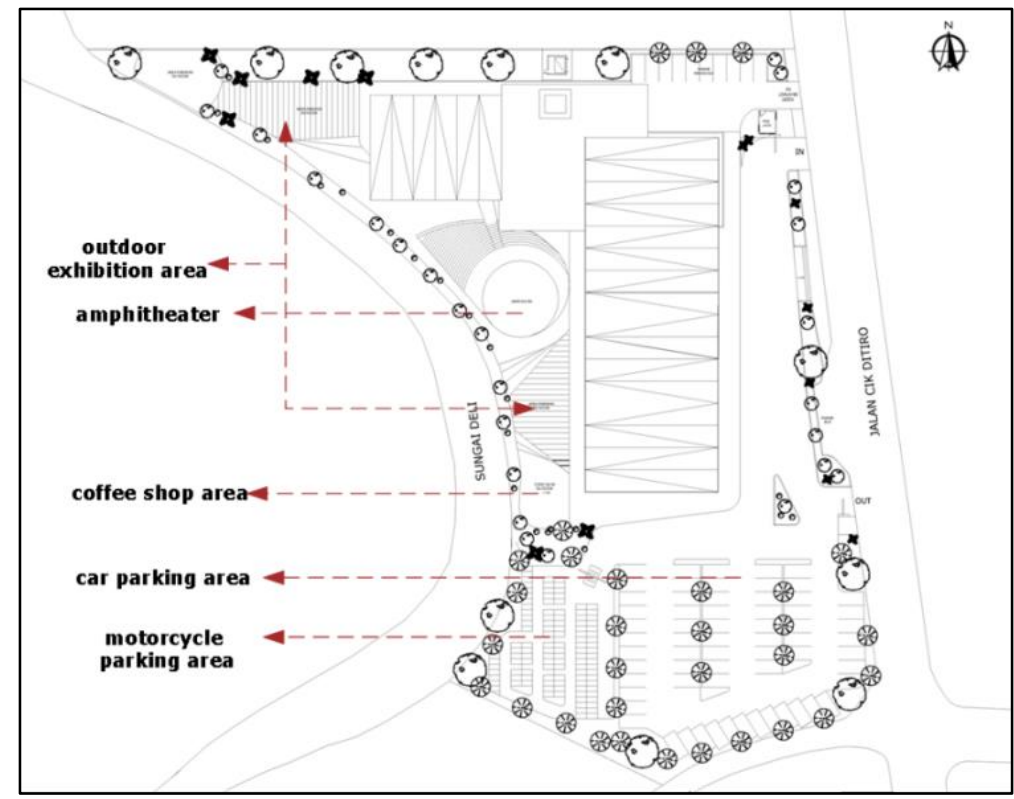

Figure 2 Main Concept 


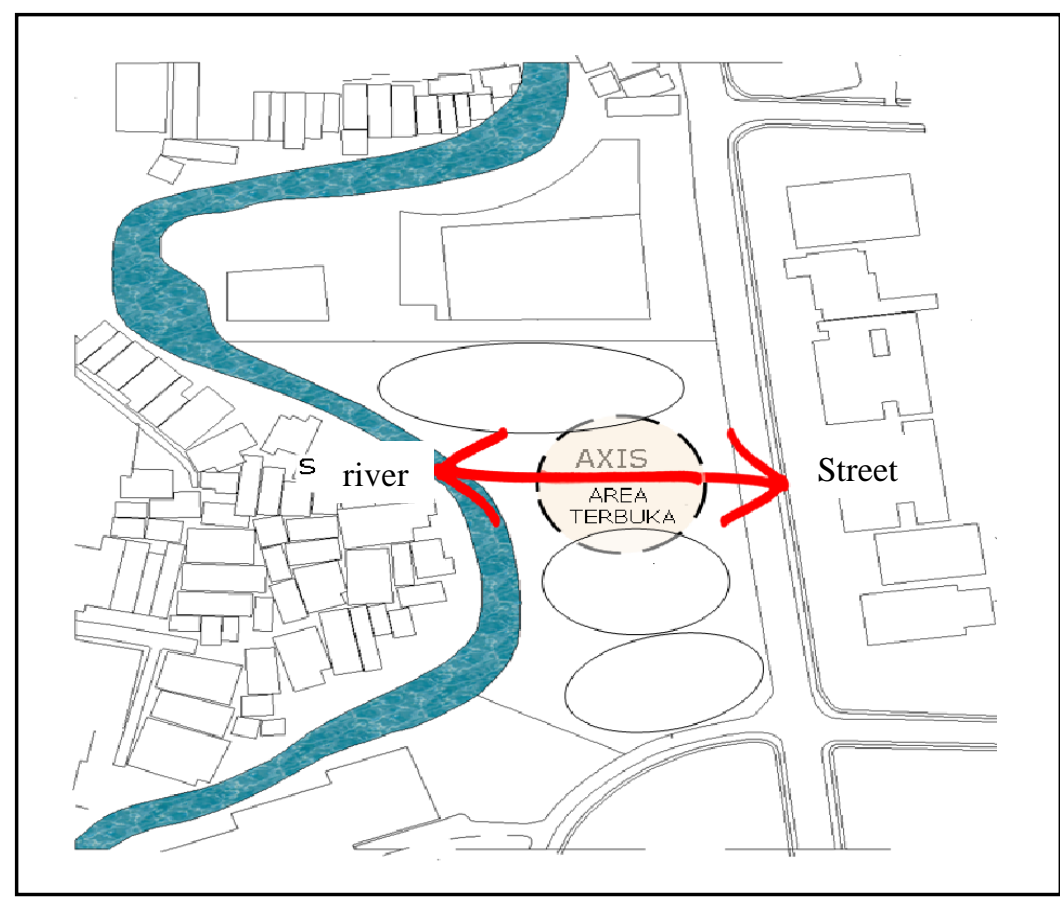

Figure 3 Siteplan Concept

Cik Ditiro road which is leading to the main road act as the access point from and to the area. The parking area for gallery visitors is in the south of Cik Ditiro street. For parking manager and service, the lane is on the north of CikDitiro road (Figure 4).

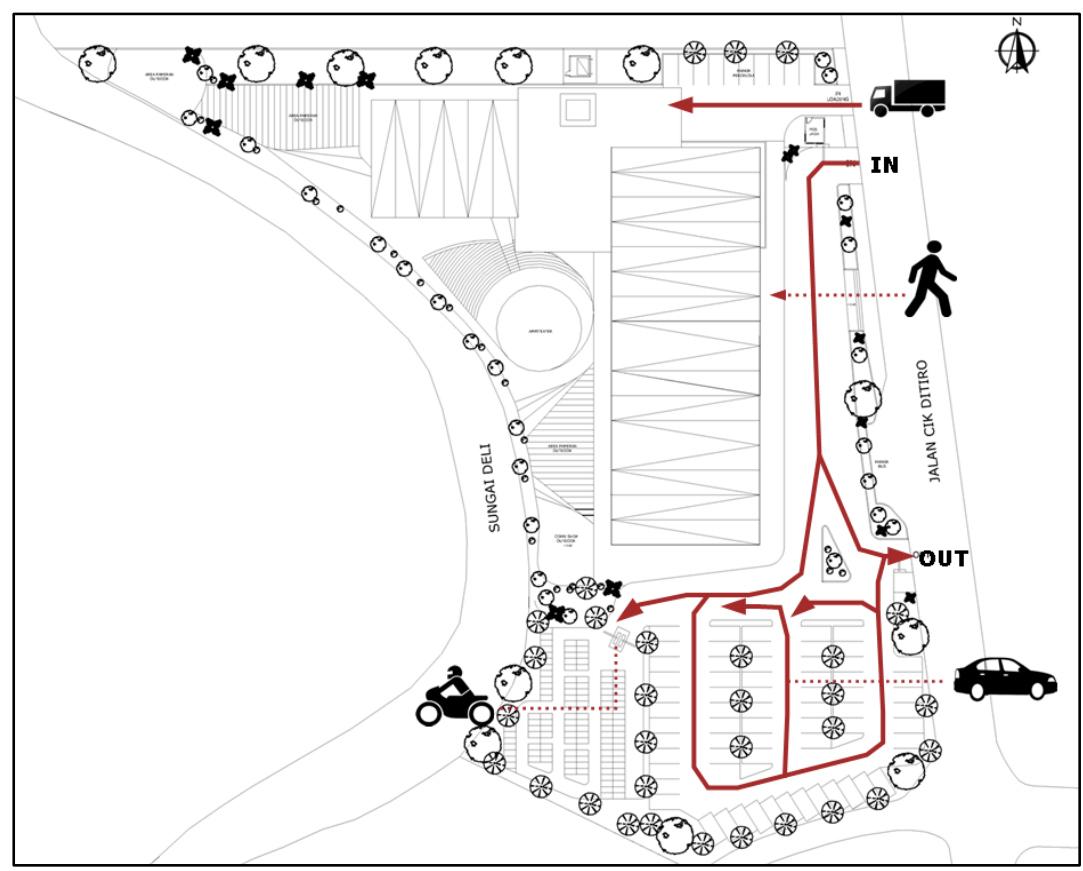

Figure 4 Circulation Concept

\section{Mass Composition Concept}

The masses use a sky cross to connect between spaces on each floor to create an compelling circulation to enjoy the works that exist in each location between galleries. The game of sky cross creates a void that allows visitors to see in every direction both from each floor and each 
room. Masses of material made of glass along with the sky cross aim so that visitors can see from outside the sky cross inside the building (Figure 5).

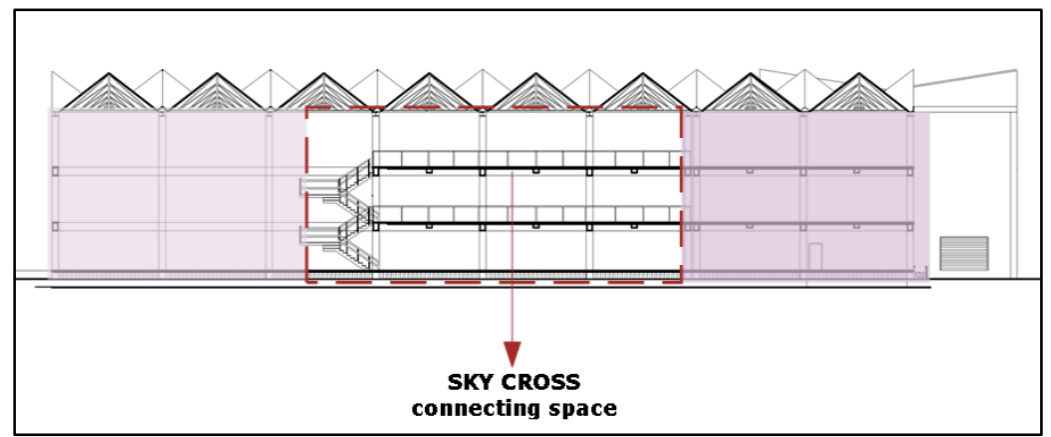

Figure 5 Mass Composition Concept

Inner Layout Concept

The system used in the gallery is a free flow of one space where the room organizes in an abstract pattern with a partition wall panel that able to change at any time. The design of this gallery is by having skylights along the ramp so that the strong character of the slope access through the sunlight into the building also becomes a point of view for visitors because every visitor who walks will see the artwork hanging on the skylight as seen below (Figure 6).

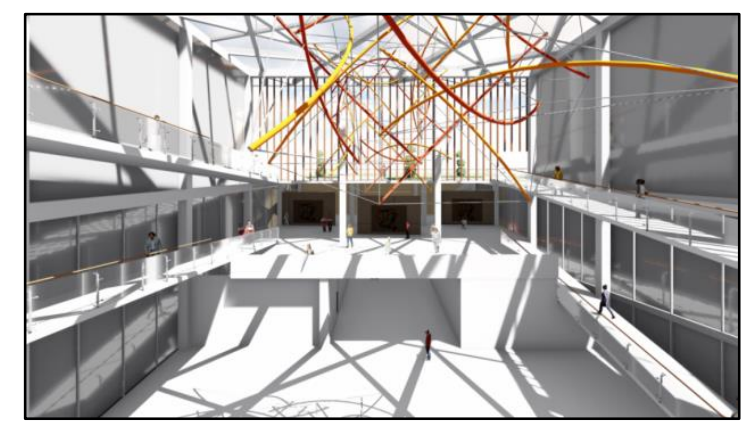

Figure 6 Inner Concept

Lighting in the gallery uses fluorescent and LED lamps that minimize UV waves (electromagnetic spectrum for objects or collections in the gallery) so that it does not damage the artwork in the gallery (Figure 7).

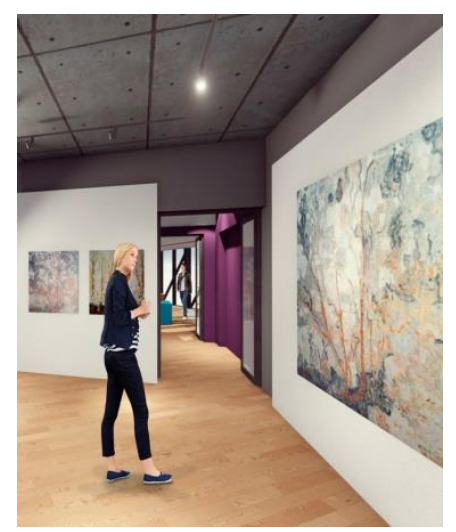

Figure 7 Lighting Gallery 


\section{Gallery Flow Concept}

When entering, there is a 3D art exhibition area under the skylight area on the 1st floor also has lots of food areas that can be enjoyed by visitors (Figure 8). On the 2nd floor, there will be a permanent exhibition of paintings which means the paintings on display will not change, on the next level there will be a sculpture exhibition after that going up to the outdoor rooftop area which commonly functions for outdoor displays usually for events but when there are no events visitors can enjoy the atmosphere the amphitheater and behind the river (Figure 9-10).

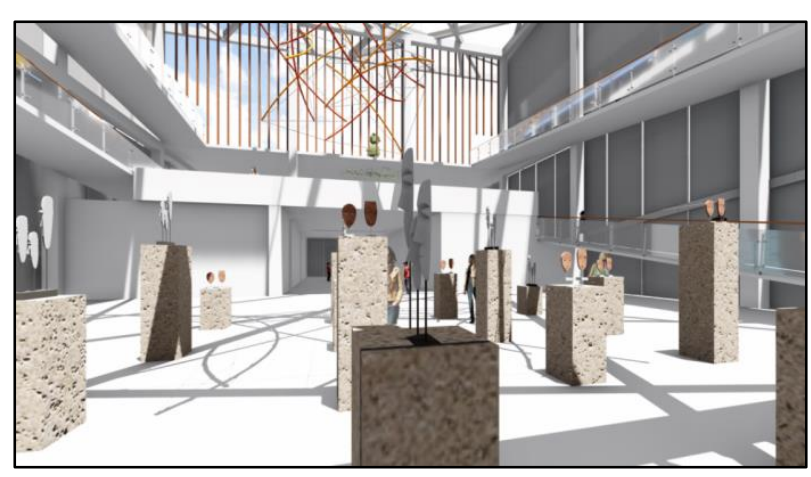

Figure 8 Flow Gallery

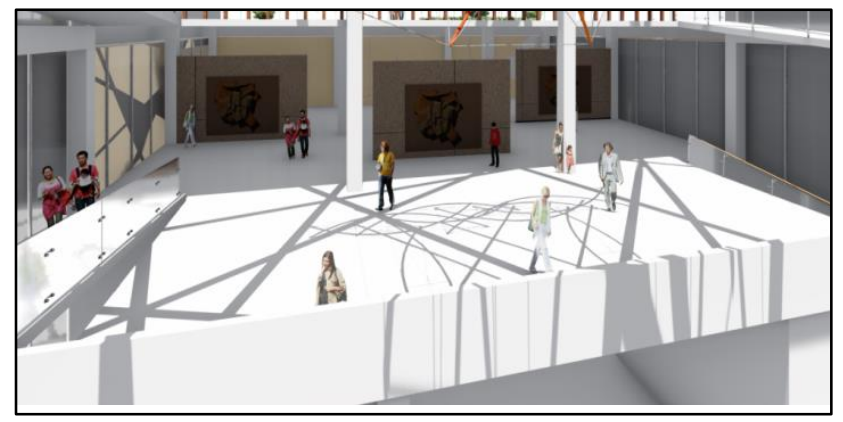

Figure 9 2d Painting Exhibition

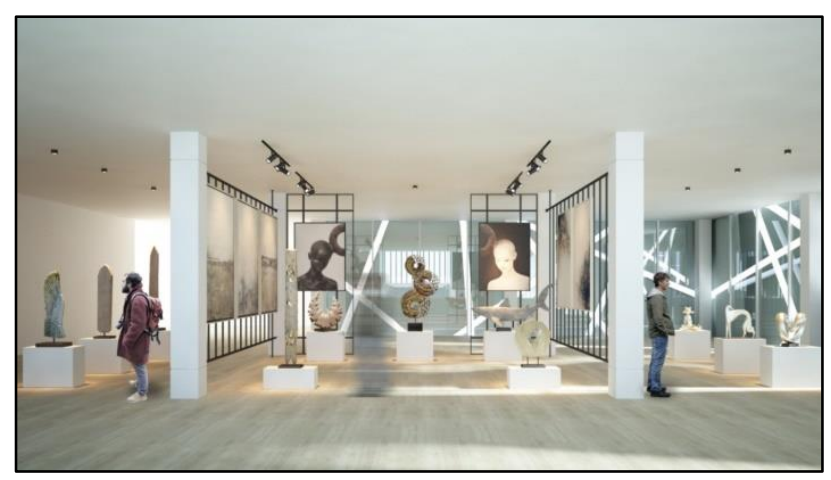

Figure 10 Sculpture Exhibition

\section{Conclusion}

The importance of art and culture in a city gives color to life and gives the place its characteristics. In this case, craftsmanship will be preserved and preserved in the city of Medan. Therefore, it is very much needed a space to accommodate all art activities in the city of Medan. 
Contemporary Art Gallery is an art space with various other supporting activities. One of the centers of attention is the pattern of visitor and artist relations with the gallery. The relationship referred to in this case, is how much the relationship between the activities of space in the Gallery. The gallery hopes to be a productive space to introduce and provide amusing knowledge for local people and tourists.

\section{Acknowledgment}

This research is a study of contemporary art galleries which intends so that art in the city of Medan is increasingly developing and the availability of space for art lovers to produce works and people who can enjoy works of art.

\section{REFERENCES}

[1] J. C. \&. C. A. J. r. Snyder, Pengantar Arsitektur Perancangan Pusat Pengembangan Seni Rupa, Jakarta: Erlangga, 1979.

[2] Soedarso SP. Tinjauan Seni Sebuah Pengantar Apresiasi Seni. Yogyakarta : Suku Dayar Sana. 1990

[3] Sumardjo, J. Filsafat Seni, ITB, Bandung. 2000

[4] Galeri Nasional, Syarat-Syarat Galeri Kontemporer , 2009

[5] Sakul, M. D., and Erdiono, D. "Implementasi Aliran Seni Ekspresionisme dalam Karya Arsitektur." Media Matrasain 9, no. 2: 75-92. 2012 